\title{
PENGATURAN ALIH TEKNOLOGI PADA KEGIATAN PENANAMAN MODAL UNTUK PERCEPATAN PENGUASAAN TEKNOLOGI DI INDONESIA
}

\author{
Candra Irawan \\ Fakultas Hukum Universitas Bengkulu \\ candrawan73@gmail.com
}

\begin{abstract}
In the future, Indonesia has the technology transfer regulations in direct investment activities. This is necessary because of the presence of foreign companies in Indonesia was not followed by the transfer of technology to Indonesia. While foreign companies are getting a lot of investment facilities (tax breaks, duty exemptions, land, repatriation of profits) utilized large Indonesian market (245 million people). State must act to force the transfer of technology through the rule of law, good arrangement sui generis and spread on other relevant regulations.
\end{abstract}

Key words: Technology Transfer, Investment

\begin{abstract}
ABSTRAK
Di masa depan diharapkan Indonesia memiliki peraturan alih teknologi dalam kegiatan penanaman modal langsung. Hal ini dibutuhkan karena kehadiran perusahaan asing di Indonesia ternyata tidak diikuti dengan terjadinya alih teknologi kepada Indonesia. Sementara perusahaan asing tersebut mendapatkan banyak fasilitas penanaman modal (keringanan pajak, pembebasan bea masuk, lahan, repatriasi keuntungan) memanfaatkan pasar Indonesia yang besar (245 juta penduduk). Negara harus berperan memaksa terjadinya alih teknologi melalui aturan hukum, baik pengaturan secara sui generis maupun tersebar pada peraturan lain yang relevan.
\end{abstract}

Kata Kunci: pengaturan, Alih Teknologi, Penanaman Modal,

\section{PENDAHULUAN}

Pasal 1 angka (2) Undang-Undang Republik Indonesia Nomor 18 Tahun 2002 Tentang Sistem Nasional Penelitian, Pengembangan, Dan Penerapan Ilmu Pengetahuan Dan Teknologi, menyebutkan teknologi adalah cara atau metode serta proses atau produk yang dihasilkan dari penerapan dan pemanfaatan berbagai disiplin ilmu pengetahuan yang menghasilkan nilai bagi pemenuhan kebutuhan, kelangsungan, dan peningkatan mutu kehidupan manusia. Sedangkan alih teknologi pada Pasal 1 Angka (11)

Candra Irawan, Pengaturan Alih Teknologi Pada Kegiatan Penanaman Modal Untuk Percepatan Penguasaan Tteknologi Di Indonesia 
p-ISSN: 1693-766X ; e-ISSN: 2579-4663, Vol. 28, No. 1, Januari 2019

adalah pengalihan kemampuan memanfaatkan dan menguasai ilmu pengetahuan dan teknologi antar lembaga, badan, atau orang, baik yang berada di lingkungan dalam negeri maupun yang berasal dari luar negeri ke dalam negeri dan sebaliknya.

Indonesia merupakan negara anggota World Trade Organization (WTO) dan sudah meratifikasi konvensi WTO melalui Undang-Undang Nomor 7 Tahun 1994. Salah satu lampiran WTO adalah Agreement on Trade Related Aspects of Intellectual Property Rights (TRIPs Agreement). Konsekuensinya Indonesia telah menyesuaikan berbagai undang-undang Hak Kekayaan Intelektual (HKI) dengan ketentuan TRIPs Agreement ${ }^{1}$. Berdasarkan Article 7 TRIPs Agreement, TRIPs bertujuan:

The protection and enforcement of intellectual property rights should contribute to the promotion of technological innovation and to the transfer and dissemination of technology, to the mutual advantage of producers and users of technological knowledge and in a manner conducive to social and economic welfare, and to a balance of rights and obligations.

Meskipun salah satu tujuan TRIPs Agreement adalah memudahkan penyebaran teknologi dan alih teknologi di dunia, tetapi anehnya UndangUndang HKI Indonesia dan undang-undang yang relevan lainnya tidak satupun mengatur mengenai hal ini secara jelas di dalam pasal-pasalnya. Padahal alih teknologi menjadi sarana strategis dalam meningkatkan penguasaan dan pemanfaatan ilmu pengetahuan dan teknologi (IPTEK). Maka cukup beralasan alih teknologi saat ini di Indonesia belum berlangsung dengan mulus, baik karena belum terdapatnya kesamaan persepsi dan konsepsi tentang alih teknologi maupun karena alasan politik ekonomi negara maju yang tidak sepenuhnya "ikhlas" dalam membantu negara berkembang untuk menguasai dan memanfaatkan teknologi dari negara maju. ${ }^{2}$ Termasuk juga karena belum efektifnya peraturan perundang-

${ }^{1}$ Hak Cipta diatur dengan Undang-Undang Nomor 19 Tahun 2002 dan mulai diberlakukan tahun 2003, Paten diatur dengan Undang-Undang Nomor 14 Tahun 2001, Merek diatur dengan Undang-Undang Nomor 15 Tahun 2001, Indikasi georgrafis dan indikasi asal termasuk juga diatur dalam undang-undang ini, Rahasia Dagang diatur dengan Undang-Undang Nomor 30 Tahun 2000, Perlindungan Varietas Tanaman dengan Undang-Undang Nomor 29 Tahun 2000, Desain Industri diatur dengan Undang-Undang Nomor 31 Tahun 2000, dan Desain Tata Letak Sirkuit Terpadu diatur dengan Undang-Undang Nomor 32 Tahun 2000.

${ }^{2}$ Menteri Negara Riset dan Teknologi RI, Kata Pengantar Buku Achmad Zen Umar Purba, Perjanjian TRIPs dan Beberapa Isu Strategis, Bandung-Jakarta: PT.Alumni dan BPFH Universitas Indonesia, 2011, hlm. x.

Candra Irawan, Pengaturan Alih Teknologi Pada Kegiatan Penanaman Modal Untuk Percepatan Penguasaan Tteknologi Di Indonesia 
Supremasi Hukum :Jurnal Penelitian Hukum

p-ISSN: 1693-766X ; e-ISSN: 2579-4663, Vol. 28, No. 1, Januari 2019

undangan dan kebijakan IPTEK yang ditetapkan, dan masih kurangnya pengetahuan dan pemahaman masyarakat terhadap regulasi dan kebijakan IPTEK secara keseluruhan. ${ }^{3}$

Indonesia telah memiliki Peraturan Pemerintah (PP) Nomor 20 Tahun 2005 tentang Alih Teknologi Kekayaan Intelektual Serta Hasil Kegiatan Penelitian dan Pengembangan. PP ini dibuat bukan dalam modal asing (PMA) maupun penanaman modal dalam negeri (PMDN). Padahal lebih dari $80 \%$ teknologi yang digunakan di Indonesia berasal dari teknologi pihak asing, baik melalui PMA maupun melalui jual beli teknologi. Beberapa peraturan perundang-undangan yang memiliki kaitan dengan persoalan alih teknologi, antara lain:

1. Undang-Undang Nomor 18 Tahun 2002 tentang Sistem Nasional Penelitian, Pengembangan dan Penerapan Ilmu Pengetahuan.

2. Undang-Undang Nomor 25 Tahun 2007 tentang Penanaman Modal.

3. Undang-Undang Nomor 3 Tahun 2014 tentang Perindustrian.

4. Undang-Undang Nomor 13 Tahun 2003 tentang Ketenagakerjaan.

5. Undang-Undang Nomor 7 Tahun 1994 tentang Pengesahan Agreement Establishing The World Trade Organization (Persetujuan Pembentukan Organisasi Perdagangan Dunia).

6. Undang-Undang Nomor 29 Tahun 2000 tentang Perlindungan Varietas Tanaman.

7. Undang-Undang Nomor 30 Tahun 2000 tentang Rahasia Dagang.

8. Undang-Undang Nomor 31 Tahun 2000 tentang Desain Industri.

9. Undang-Undang Nomor 32 Tahun 2000 tentang Desain Tata Letak Sirkuit Terpadu.

10. Undang-Undang Nomor 14 Tahun 2001 tentang Paten.

11. Undang-Undang Nomor 15 Tahun 2001 tentang Merek.

12. Undang-Undang Nomor 19 Tahun 2002 tentang Hak Cipta.

13. Peraturan Pemerintah (PP) Nomor 20 Tahun 2005 tentang Alih Teknologi Kekayaan Intelektual Serta Hasil Kegiatan Penelitian dan Pengembangan

14.Peraturan Pemerintah Nomor 27 Tahun 2005 tentang Tata Cara Pelaksanaan Paten Oleh Pemerintah.

15.Keputusan Presiden RI Nomor 15 Tahun 1997 tentang Perubahan Keputusan Presiden Nomor 24 Tahun 1979 Pengesahan Paris Convention For The Protection of Industrial Property dan Convention Establishing The World Intellectual Property Organization.

3 Menteri Negara Riset dan Teknologi RI, Kata Pengantar Buku Sabartua Tampubolon, Politik Hukum IPTEK Di Indonesia, Yogaykarta: Janabadra University Press dan KEPEL Press, 2013, hlm. v.

Candra Irawan, Pengaturan Alih Teknologi Pada Kegiatan Penanaman Modal Untuk Percepatan Penguasaan Tteknologi Di Indonesia 
Supremasi Hukum :Jurnal Penelitian Hukum

p-ISSN: 1693-766X ; e-ISSN: 2579-4663, Vol. 28, No. 1, Januari 2019

16. Keputusan Presiden RI Nomor 16 Tahun 1997 tentang Pengesahan Patent Cooperation Treaty (PCT) and Regulation Under the Patent Cooperation Treaty.

17. Keputusan Presiden RI Nomor 17 Tahun 1997 tentang Pengesahan Trade Mark Law Treaty.

18. Keputusan Presiden RI Nomor 18 Tahun 1997 tentang Pengesahan Berne Convention for the Protection of Literary an Artistic Works (Berne Convention).

19. Keputusan Presiden RI Nomor 19 Tahun 1997 tentang Pengesahan World Intellectual Poperty Organization Copyright Treaty (WCT).

20.Keputusan Presiden RI Nomor 74 Tahun 2004, Pengesahan WIPO Performance and Phonograms Treaty (WPPT).

Di dalam Undang-Undang Nomor 14 Tahun 2001 ada dua saluran untuk dapat terjadinya alih teknologi, yaitu melalui kontrak lisensi yang diatur Pasal 69 - 87, dan pelaksanaan paten oleh pemerintah (government use principle) terkait kepentingan pertahanan dan keamanan, serta kebutuhan sangat mendesak untuk kepentingan masyarakat yang diatur Pasal 99 - 103. Dua saluran tersebut secara faktual tidak banyak berpengaruh terhadap penguasaan teknologi maju oeh bangsa Indonesia. Penyebabnya, antara lain:

Pertama, kontrak lisensi dilakukan secara privat antara swasta dengan swasta ( $B$ to $B$ ) dan tunduk pada hukum privat (hukum perdata) yang berasaskan kebebasan berkontrak, konsensualisme dan pacta sun servanda. PSA jelas lebih kuat kedudukannya dalam pembuatan kontrak lisensi dibandingkan dengan PSA/BUMN/BUMD, sehingga isi kontrak lebih melindungi kepentingan PSA, terutama terkait dengan perlindungan terhadap teknologi (HKI) yang dimilikinya. Demikian pula yang terjadi pada lisensi wajib (compulsory license). Sejauh ini belum banyak berperan dalam mempercepat penguasaan teknologi maju (teknologi terbaru) oleh PSA/BUMN/BUMD, sehingga Indonesia masih sangat bergantung pada produk-produk asing tanpa mampu membuat produk substitusinya di dalam negeri. Hasil penelitian Mas Rahmah tahun 2006, menunjukkan bahwa efektivitas compulsory license bagi percepatan proses alih teknologi dirasa masih kurang. Hal ini dikarenakan jenis lisensi yang sifatnya wajib ini jarang dipilih dalam upaya menguasai dan mengembangkan teknologi. ${ }^{4}$

\footnotetext{
${ }^{4}$ Mas Rahmah, Compulsory Licensing Bagi Percepatan Alih Teknologi Di Indonesia, http://repo.unair.ac.id/data/richfiles/abstrak\%20Sosial\%20upload(4).pdf, diunduh tgl 21/03/2012.

Candra Irawan, Pengaturan Alih Teknologi Pada Kegiatan Penanaman Modal Untuk Percepatan Penguasaan Tteknologi Di Indonesia
} 
p-ISSN: 1693-766X ; e-ISSN: 2579-4663, Vol. 28, No. 1, Januari 2019

Hal senada sebelumnya sudah pernah terungkap dari hasil penelitian Budi Santoso, dkk tahun 1999. 5

Kedua, sejauh ini prinsip pelaksanaan oleh Pemerintah (government use) hanya dimanfaatkan untuk kepentingan jangka pendek terkait dengan kebutuhan masyarakat yang mendesak. Misalnya adanya wabah penyakit tertentu yang mengharuskan tersedianya obat-obatan dengan harga yang terjangkau. Tidak ada kegiatan alih teknologi didalamnya. Artinya secara yuridis belum ada pengaturan alih teknologi secara khusus dalam sistem hukum ekonomi Indonesia.

Undang-Undang Nomor 25 Tahun 2007 tentang Penanaman Modal, alih teknologi hanya diatur secara sumir pada Pasal 10 Ayat (4) yang menyatakan bahwa perusahaan penanaman modal yang mempekerjakan tenaga kerja asing diwajibkan menyelenggarakan pelatihan dan melakukan alih teknologi kepada tenaga kerja Indonesia sesuai ketentuan peraturan perundang-undangan yang berlaku.

Hasil penelitian Deden Purnama Alam tahun 2011, menunjukan bahwa pengaturan hukum lebih lanjut mengenai hal tersebut terdapat pada Pasal 45 Ayat (2) huruf a dan huruf b Undang-Undang Ketenagakerjaan jo Pasal 21 Ayat (1) Peraturan Menteri Nomor Per.02/Men/III/2008. Belum ada ketentuan khusus yang mengatur mengenai pengalihan teknologi berwujud, kecuali hanya terkait dengan pendidikan dan pelatihan tenaga kerja. Pengawasan terhadap hal tersebut juga sangat lemah, karena hanya berdasarkan laporan dari perusahaan asing semata. ${ }^{6}$ Menurut Tjuk Kuswartojo, alih teknologi secara total atau seluruh sistem, agaknya tidak gampang, bahkan rasanya tidak mungkin karena itu mestinya harus ada siasat. Sejauh ini hal-hal apa yang harus dialihkan dari negara maju ke negara berkembang dan apa yang harus dikembangkan di dan oleh negara berkembang sendiri tidak diketemukan adanya program internasional dan multilateral yang dapat menjadi acuan. Oleh karena itu negara berkembang harus menyusun siasatnya sendiri. ${ }^{7}$ Salah satu siasat yang mungkin dipilih, adalah melalui instrumen hukum. Hukum harus memberikan pengaturan yang jelas sebagai sarana untuk mengatur alih teknologi. Hal terpenting

\footnotetext{
${ }^{5}$ Budi Santoso, dkk, Pelaksanaan Kontrak Lisensi Paten Dalam Pelaksanaan Alih Teknologi, http://eprints.undip.ac.id/20607/2/2466-ki-fh-00-a.pdf, diunduh tanggal 21/03/2012.

6Deden Purnama Alam, Kajian Terhadap Pengaturan Alih Teknologi Dalam Kegiatan Penanaman Modal, http://Repository.Unila.Ac.Id:8180/Dspace/Handle/123456789/2524, Diunduh Tanggal 21/03/2012.

${ }^{7}$ Tjuk Kuswartojo, Agenda 21, GEF dan Alih Teknologi, Jurnal Teknologi Lingkungan, Vol 3, No. 3 September 2002, Hlm. 176-177.
}

Candra Irawan, Pengaturan Alih Teknologi Pada Kegiatan Penanaman Modal Untuk Percepatan Penguasaan Tteknologi Di Indonesia 
p-ISSN: 1693-766X ; e-ISSN: 2579-4663, Vol. 28, No. 1, Januari 2019

yang harus diperhatikan adalah masalah yang bersifat teknis yuridis, masalah substansi aturan hukum yang akan diciptakan dan arah politik hukum nasional. 8

Maka dari itu, persoalan kontekstual penguasaan teknologi maju yang dihadapi Indonesia dilihat dari perspektif filosofis, yuridis konstitusional dan sosiologis, aspek kelembagaan teknologi, Sumber Daya Manusia (SDM), perkembangan perekonomian nasional dan kesiapan bangsa Indonesia mengembangkan dan menguasai teknologi maju.

\section{PENGATURAN ALIH TEKNOLOGI DI INDONESIA (IUS CONSTITUENDUM)}

Landasan konstitusional pengaturan alih teknologi terdapat dalam Undang-Undang Dasar Negara Republik Indonesia 1945, yaitu:

a. Pasal 28C Ayat (1) yang berbunyi: setiap orang berhak mengembangkan diri melalui pemenuhan kebutuhan dasarnya, berhak mendapat pendidikan dan memperoleh manfaat dari ilmu pengetahuan dan teknologi, seni dan budaya, demi meningkatkan kualitas hidupnya dan demi kesejahteraan umat manusia.

b. Pasal 31 Ayat (5), yang berbunyi: pemerintah berkewajiban memajukan ilmu pengetahuan dan teknologi dengan menjunjung tinggi nilai-nilai agama dan persatuan bangsa untuk kemajuan peradaban serta kesejahteraan umat manusia.

Negara berkewajiban mensejahterakan rakyat Indonesia, salah satunya melalui penguasaan ilmu pengetahuan dan teknologi maju. Pengaturan alih teknologi merupakan suatu keharusan. Pengalaman negara berkembang yang kemudian menuju menjadi negara maju yang menguasai teknologi maju sejajar dengan negara yang sudah lebih dahulu maju mensyaratkan adanya aturan alih teknologi. Misalnya China, khususnya alih teknologi yang berasal dari penanaman modal asing ke dalam negeri, disamping berbagai kebijakan dan program mandiri untuk menghasilkan teknologi dalam negeri. Tanpa ada aturan yang jelas dan pemaksaan secara legal perusahaan penanaman modal asing tidak mau mengalihkan teknologi yang dimilikinya kepada Indonesia melalui instrumen perjanjian (lisensi) dan alasan perlindungan Hak Kekayaan Intelektual (Hak Cipta, Paten, Rahasia Dagang, Desain Indusri, Desain Tata Letak Sirkuit Terpadu, Perlindungan Varietas Tanaman). Terbukti, menurut Zuhal Keberhasilan pemerintah

${ }^{8}$ Ambar Wariati, Implementasi Mengenai Hukum Alih Teknologi, Http://EJournal.Stie-Aub.Ac.Id/Index.Php/Probank/Article/View/102/84, Diunduh Tanggal 20/03/2012.

Candra Irawan, Pengaturan Alih Teknologi Pada Kegiatan Penanaman Modal Untuk Percepatan Penguasaan Tteknologi Di Indonesia 
p-ISSN: 1693-766X ; e-ISSN: 2579-4663, Vol. 28, No. 1, Januari 2019

menarik investasi ke sektor riil ternyata dinodai oleh kegagalan proses alih teknologi. Sehingga industri nasional tak mampu menghasilkan produk unggulan bermerk lokal sebagai hasil kerjasama dengan pabrikan kelas dunia yang beroperasi di Indonesia. Hal ini berbeda jauh dengan Malaysia yang berhasil memaksa Mitsubishi membantu mereka membuat mobil nasional merk Proton atau China yang sukses mengembangkan komputer jinjing Lenovo atas bantuan raksasa komputer IBM. Pemerintah China berhasil mendorong IBM melakukan alih teknologi. China memperbolehkan IBM masuk ke pasar mereka yang sangat besar, tapi mereka harus membuat inovasi untuk produk baru asli China. IBM diberi insentif, tapi di sisi lain ditekan untuk membuat produk baru, dan jadilah Lenovo. ${ }^{9}$

Bukti lainnya, Menteri Perindustrian MS Hidayat mengatakan bahwa Jepang telah ingkar janji kepada Indonesia. Pasalnya, para investor Jepang kurang mau merealisasikan program pembangunan kapasitas industri atauManufacturing Industry Development Center (Midec) yang telah disepakati RI-Jepang beberapa tahun silam. Padahal, Midec sebagai penyeimbang antara terbukanya pasar Indonesia lewat perdagangan bebas bilateral RI-Jepang atau Indonesia-Japan Economic Partnership Agreement (IJ-EPA).Midec merupakan salah satu syarat dari IJ-EPA yang diminta Indonesia jika Jepang ingin masuk ke pasar Indonesia, tetapi faktanya Capacity building untuk industri kurang berjalan sehingga alih teknologi tidak terjadi. ${ }^{10}$ Indonesia dirugikan, Jepang mendapatkan pasar besar untuk produknya, sementara Indonesia tidak mendapatkan teknologi. Berbeda dengan China, yang berhasil memanfaatkan perusahaan penanaman modal asing untuk meningkatkan kapasitas penguasaan teknologi nasional, seperti yang diuraikan oleh Leong Chan dan Fahad Aldhaban:

"As an attractive destination for many foreign direct investment (FDI), China's economic growth has greatly benefited from FDI and technology transfer. Since the economic reform in 1978, numerous advanced technologies and management techniques are being transferred into China from MNCs. The level of technology, management and market competition capability of China's indigenous industries are largely being improved. One thing worth our notice is that China is stillunder the transition from a planned to market-orientated

${ }^{9}$ Redaksi, Pemerintah Tak Mampu Paksa Investor Asing Lakukan Alih Teknologi Kebijakan Investasi Berorientasi Jangka Pendek, Neraca.do.id, Rabu, 13/06/2012, diakses 18/07/2012

\footnotetext{
${ }^{10}$ Redaksi, Perlu Paksa Asing Lakukan Transfer Teknologi Alih Teknologi Sektor Industri Berjalan Lambat, Neraca.Co.Id, Jumat, 17/02/2012 Diakses 18/07/2014.
}

Candra Irawan, Pengaturan Alih Teknologi Pada Kegiatan Penanaman Modal Untuk Percepatan Penguasaan Tteknologi Di Indonesia 
p-ISSN: 1693-766X ; e-ISSN: 2579-4663, Vol. 28, No. 1, Januari 2019

economy, and thus the social structure and government policy have gone through many changes in the new decade. Forexample, China's acceptance into the World Trade Organization (WTO) in 2001 has further accelerated thetransition. These changes contributed many direct or indirectimpacts on the technology transfer activities in China. Equity joint venture is the framework preferred by the Chinese authorities for acquiring technology from abroad. An international joint venture in China typically involvestechnology transfers from the foreign MNCs to their Chinese partners. Technological progress in some Chinese industriesstill relies heavily on imported hardware equipment andforeign technologies. This has put more pressure on domesticpartners in the joint ventures to increase their internal capacities to absorb foreign knowledge. However,organizational learning can be a lengthy, complex anddynamic process and its success is influenced by variousfactors originating from many different sources. Experience has shown that the balance of competitive powerbetween joint venture partners via knowledge transfers isdifficult to control solely through policies, agreements, orother structural methods. It is the learning pace of the parties, as motivated by their respective positions". 11

Terlihat bahwa tidak mudah meminta perusahaan penanaman modal asing dengan suka rela melakukan alih teknologi, dan dengan berbagai upaya menghalangi terjadinya alih teknologi. Oleh karena itu, negara harus mengambil peran melalui instrumen hukum atau kebijakan yang dapat memaksa terjadi alih teknologi untuk kesejahteraan bangsa. Betul yang dikatakan Leong Chan dan Fahad Aldhaban bahwa:

"International technology transfer is a complicated processbecause the participants come with different goals andstrategies. The process is influenced by many domestic andexotic factors. In order to achieve mutual prosperity,participants have to work closely with others even thoughthey have fundamentally different interests. Finding ways ofincreasing the effectiveness of technology transfer hasstrategic implications for both host governments and foreign companies.From the perspective of host government, there is not asingle strategy without its drawbacks. Therefore, technologyimporters should adjust their technology acquisition policy onthe basis of their actual level of economic development,technological accumulation and long-term industrial

${ }^{11}$ Leong Chan, Fahad Aldhaban, Technology Transfer To China: With Case Studies In The High-Speed Rail Industry, PICMET 2009 Proceedings, August 2-6, Portland, Oregon USA, http://www.deepdyve.com/lp/institute-of-electrical-andelectronics-engineers/technology-transfer-to china-with-case-studies-in-the-highspeed-rail, diakses 18/07/2014.

Candra Irawan, Pengaturan Alih Teknologi Pada Kegiatan Penanaman Modal Untuk Percepatan Penguasaan Tteknologi Di Indonesia 
plans. Decision makers should take a strategic view of technologytransfer that can facilitate indigenous industry's innovationcapability. A fairer policy should be considered for bothdomestic enterprises and foreign joint ventures. From the point of view of the foreign MNCs, they need to conform tolocal policy of host nation. A good balance should beachieved between the protection of intellectual properties andtransferring of knowledge. To conclude, mutual understandings are required for both technology importersand exporters. This will foster the long-term prosperity andsuccess of international technology transfer". ${ }^{12}$

Oleh karena itu, Indonesia perlu membuat aturan alih teknologi. Pembuatan aturan tersebut dapat ditempuh dengan dua cara, yaitu melalui amandemen atau revisi berbagai peraturan perundang-undangan yang sudah ada, dan membuat undang-undang khusus alih teknologi(sui generis).Beberapa hal yang penting diatur adalah:

1. Aturan kontrak investasi atau lisensi teknologi yang tidak membatasi terjadinya alih teknologi.

2. Kewajiban alih teknologi dari perusahaan penanaman modal asing kepada perusahaan nasional.

3. Proses atau mekanisme alih teknologi yang harus dijalankan oleh setiap perusahaan penanaman modal asing.

4. Kewajiban perusahaan penanaman modal asing yang memiliki teknologi strategis atau yang sangat penting bagi Indonesia untuk menggandeng perusahaan nasional (BUMN atau swasta) dan kewajiban alih teknologi.

5. Kewajiban peningkatan kapasitas perusahaan nasional (manajemen, sumber daya manusia, hardware) untuk memudahkan terjadi alih teknologi dari perusahaan penanaman modal asing.

\section{PENUTUP}

Bagi Indonesia, aturan alih teknologi merupakan suatu hal yang penting. Pasar yang besar (245 juta penduduk) harus mampu dimanfaatkan sebagai salah satu kekuatan untuk memaksa perusahaan penanaman modal asing bersedia membuat komitmen alih teknologi dan melaksanakannya secara konsisten. Secara hukum, aturan yang jelas dan tegas mengenai alih teknologi harus dibuat dan segera diimplementasikan.

\section{${ }^{12}$ Ibid}

Candra Irawan, Pengaturan Alih Teknologi Pada Kegiatan Penanaman Modal Untuk Percepatan Penguasaan Tteknologi Di Indonesia 
Supremasi Hukum :Jurnal Penelitian Hukum

p-ISSN: 1693-766X ; e-ISSN: 2579-4663, Vol. 28, No. 1, Januari 2019

\section{DAFTAR PUSTAKA}

Achmad Zen Umar Purba, 2011, Perjanjian TRIPs dan Beberapa Isu Strategis, Bandung-Jakarta: PT. Alumni dan BPFH Universitas Indonesia.

Ambar Wariati, Implementasi Mengenai Hukum Alih Teknologi, Http://EJournal.Stie-Aub.Ac.Id/Index.Php/Probank/Article/View/102 /84, Diunduh Tanggal 20/03/2012.

Budi Santoso, dkk, 1999, Pelaksanaan Kontrak Lisensi Paten Dalam Pelaksanaan Alih Teknologi, http://eprints.undip.ac.id/20607/2/2466-ki-fh-00-a.pdf, diunduh tanggal $21 / 03 / 2012$.

Candra Irawan, 2011, Politik Hukum Hak Kekayaan Intelektual Indonesia Kritik Terhadap WTO/TRIPs Agreement dan Upaya Membangun Hukum Kekayaan Intelektual Demi Kepentingan Nasional, Bandung: C.V. Mandar Maju.

Deden Purnama Alam, 2011, Kajian Terhadap Pengaturan Alih Teknologi Dalam Kegiatan Penanaman Modal, http:/ /Repository.Unila.Ac.Id:8180/Dspace/Handle/ 123456789/2524, Diunduh Tanggal 21/03/2012.

Dewi Astuty Mochtar, 2001, Perjanjian Lisensi Alih Teknologi Dalam Pengembangan Teknologi Indonesia, Bandung: P.T. Alumni.

Leong Chan, Fahad Aldhaban, Technology Transfer To China: With Case Studies In The High-Speed Rail Industry, PICMET 2009 Proceedings, August 2-6, Portland, Oregon USA, http://www.deepdyve.com/lp/institute-of-electrical-and-electronicsengineers / technology-transfer-tochina-with-case-studies-in-the-highspeed-rail, diakses 18/07/2014.

Mas Rahmah, 2006, Compulsory Licensing Bagi Percepatan Alih Teknologi Di Indonesia, http:/ / repo.unair.ac.id/data/richfiles/abstrak\%20Sosial\%20upload( 4).pdf, diunduh tgl 21/03/2012.

Mitchel B. Wallerstein, Mary Ellen Mogee, Roberta A. Schoen (ed), 1993, Global Dimensions of Intellectual Property Rights in Science and Technology, Washington DC: National Academy Press.

Candra Irawan, Pengaturan Alih Teknologi Pada Kegiatan Penanaman Modal Untuk Percepatan Penguasaan Tteknologi Di Indonesia 
Supremasi Hukum :Jurnal Penelitian Hukum

p-ISSN: 1693-766X ; e-ISSN: 2579-4663, Vol. 28, No. 1, Januari 2019

Redaksi, Pemerintah Tak Mampu Paksa Investor Asing Lakukan Alih Teknologi Kebijakan Investasi Berorientasi Jangka Pendek, Neraca.do.id, Rabu, 13/06/2012, diakses 18/07/2012

Redaksi, Perlu Paksa Asing Lakukan Transfer Teknologi Alih Teknologi Sektor Industri Berjalan Lambat, Neraca.Co.Id, Jumat, 17/02/2012 Diakses $18 / 07 / 2014$.

Sabartua Tampubolon, 2013, Politik Hukum IPTEK Di Indonesia, Yogyakarta: Janabadra University Press dan KEPEL Press.

Sumantoro, 1993, Masalah Pengaturan Alih Teknologi, Bandung: P.T. Alumni.

Tjuk Kuswartojo, 2002, Agenda 21, GEF dan Alih Teknologi, Jurnal Teknologi Lingkungan, Vol 3, No. 3 September 2002.

Undang-Undang Nomor 18 Tahun 2002 tentang Sistem Nasional Penelitian, Pengembangan dan Penerapan Ilmu Pengetahuan.

Undang-Undang Nomor 25 Tahun 2007 tentang Penanaman Modal.

Undang-Undang Nomor 13 Tahun 2003 tentang Ketenagakerjaan.

Undang-Undang Nomor 7 Tahun 1994 tentang Pengesahan Agreement Establishing The World Trade Organization (Persetujuan Pembentukan Organisasi Perdagangan Dunia).

Undang-Undang Nomor 29 Tahun 2000 tentang Perlindungan Varietas Tanaman.

Undang-Undang Nomor 30 Tahun 2000 tentang Rahasia Dagang.

Undang-Undang Nomor 31 Tahun 2000 tentang Desain Industri.

Undang-Undang Nomor 32 Tahun 2000 tentang Desain Tata Letak Sirkuit Terpadu.

Undang-Undang Nomor 14 Tahun 2001 tentang Paten.

Undang-Undang Nomor 15 Tahun 2001 tentang Merek.

Undang-Undang Nomor 19 Tahun 2002 tentang Hak Cipta.

Candra Irawan, Pengaturan Alih Teknologi Pada Kegiatan Penanaman Modal Untuk Percepatan Penguasaan Tteknologi Di Indonesia 
Supremasi Hukum :Jurnal Penelitian Hukum

p-ISSN: 1693-766X ; e-ISSN: 2579-4663, Vol. 28, No. 1, Januari 2019

Peraturan Pemerintah (PP) Nomor 20 Tahun 2005 tentang Alih Teknologi Kekayaan Intelektual Serta Hasil Kegiatan Penelitian dan Pengembangan

Peraturan Pemerintah Nomor 27 Tahun 2005 tentang Tata Cara Pelaksanaan Paten Oleh Pemerintah.

Keputusan Presiden RI Nomor 15 Tahun 1997 tentang Perubahan Keputusan Presiden Nomor 24 Tahun 1979 Pengesahan Paris Convention For The Protection of Industrial Property dan Convention Establishing The World Intellectual Property Organization.

Keputusan Presiden RI Nomor 16 Tahun 1997 tentang Pengesahan Patent Cooperation Treaty (PCT) and Regulation Under the Patent Cooperation Treaty.

Keputusan Presiden RI Nomor 17 Tahun 1997 tentang Pengesahan Trade Mark Law Treaty.

Keputusan Presiden RI Nomor 18 Tahun 1997 tentang Pengesahan Berne Convention for the Protection of Literary an Artistic Works (Berne Convention).

Keputusan Presiden RI Nomor 19 Tahun 1997 tentang Pengesahan World Intellectual Poperty Organization Copyright Treaty (WCT).

Keputusan Presiden RI Nomor 74 Tahun 2004, Pengesahan WIPO Performance and Phonograms Treaty (WPPT).

Candra Irawan, Pengaturan Alih Teknologi Pada Kegiatan Penanaman Modal Untuk Percepatan Penguasaan Tteknologi Di Indonesia 
Supremasi Hukum :Jurnal Penelitian Hukum

p-ISSN: 1693-766X ; e-ISSN: 2579-4663, Vol. 28, No. 1, Januari 2019

Candra Irawan, Pengaturan Alih Teknologi Pada Kegiatan Penanaman Modal Untuk Percepatan Penguasaan Tteknologi Di Indonesia 
Supremasi Hukum :Jurnal Penelitian Hukum

p-ISSN: 1693-766X ; e-ISSN: 2579-4663, Vol. 28, No. 1, Januari 2019

Candra Irawan, Pengaturan Alih Teknologi Pada Kegiatan Penanaman Modal Untuk Percepatan Penguasaan Tteknologi Di Indonesia 